OPEN ACCESS

Edited by:

Rachel Gjelsvik Tiller,

SINTEF, Norway

Reviewed by:

Russell Richards,

The University of Queensland,

Australia

Di Jin,

Woods Hole Oceanographic

Institution, United States

*Correspondence:

Kevin G. Heasman

kevin.heasman@cawthron.org.nz

Specialty section:

This article was submitted to Marine Fisheries, Aquaculture

and Living Resources,

a section of the journal

Frontiers in Marine Science

Received: 25 May 2020

Accepted: 18 August 2020

Published: 04 September 2020

Citation:

Heasman KG, Scott N,

Ericson JA, Taylor DI and Buck BH

(2020) Extending New Zealand's

Marine Shellfish Aquaculture Into

Exposed Environments - Adapting

to Modern Anthropogenic Challenges.

Front. Mar. Sci. 7:565686.

doi: 10.3389/fmars.2020.565686

\section{Extending New Zealand's Marine Shellfish Aquaculture Into Exposed Environments - Adapting to Modern Anthropogenic Challenges}

\author{
Kevin G. Heasman ${ }^{1 *}$, Nicholas Scott ${ }^{1}$, Jessica A. Ericson ${ }^{1}$, David I. Taylor ${ }^{2}$ and \\ Bela H. Buck ${ }^{1,3,4}$
}

${ }^{1}$ Aquaculture Group, Cawthron Institute, Nelson, New Zealand, ${ }^{2}$ Aquaculture New Zealand, Nelson, New Zealand, ${ }^{3}$ Marine Aquaculture, Alfred Wegener Institute Helmholtz Centre for Polar and Marine Research, Bremerhaven, Germany, ${ }^{4}$ Applied Marine Biology and Aquaculture, University of Applied Sciences Bremerhaven, Bremerhaven, Germany

New Zealand has a large exclusive economic zone (EEZ) of which the area between the 30 and $50 \mathrm{~m}$ bathymetric zone offers the most prospects for shellfish production. Only $0.3 \%$ of this zone would be required to increase New Zealand's shellfish production by 150,000 t. The Enabling Open Ocean Aquaculture Program, funded by the New Zealand Ministry of Business, Innovation and Employment, is a collaboration aiming to develop technologies that will enable the extension of aquaculture into New Zealand's harsh and challenging open ocean conditions, and facilitate adaptation to the escalating effects of climate change in inner shore environments. New Zealand has started expanding aquaculture into exposed environments, allowing farm expansion to meet increasing demand for aquaculture products but also enabling ventures into new aquatic products. Expansion into offshore developments is in direct response to mounting stakeholder interaction in inshore coastal areas. This document presents a brief overview of the potential zones for open ocean aquaculture, the influence of climate change, and two potential shellfish operational systems that may facilitate the expansion of shellfish aquaculture onto New Zealand's exposed ocean sites.

Keywords: aquaculture, climate change, shellfish, offshore and marine structure, New Zealand EEZ

\section{INTRODUCTION}

As a geographically isolated island in the southwest Pacific, New Zealand has strong historical, traditional and cultural connections to the sea (Te Ahukaramû Charles Royal, 2020) and has abundant aquaculture opportunity. The country stretches from 22 to $55^{\circ} \mathrm{S}$, straddling subtropical and sub-Antarctic waters. It is relatively remote, with its closest large neighbor over 2,000 km away (Australia). The land surface area of New Zealand is comparatively small, ranking 75th worldwide with an area of $267,710 \mathrm{~km}^{2}$, it has the world's ninth largest exclusive economic zone (EEZ) with a total of 4,083,744 $\mathrm{km}^{2}$ (Migiro, 2018). The marine zone extending to the 12 nautical mile line has an area of $144,855 \mathrm{~km}^{2}$. 
New Zealand has a strong record of seafood production in both fisheries and aquaculture, with commercial fishing and aquaculture industries generating NZ\$2.0124b ${ }^{1}\left(\mathrm{FOB}^{2}\right)$ (Seafood New Zealand, 2019) being $0.7 \%$ of New Zealand GDP in 2019, with 4,305 full time equivalents (FTEs) in direct employment and 13,468 FTEs total employment. Aquaculture in New Zealand started in 1969 with shellfish in protected fjords, then expanded to finfish aquaculture in the 1970s. Over the past 50 years, New Zealand's aquaculture industry has developed from a small but pioneering core of business-minded innovators into a professional, specialized and high-quality food production sector (Dawbar, 2004). The three main commercial aquaculture species cultured at various sites in New Zealand are (1) New Zealand Greenshell $^{\text {TM }}$ Mussels (Perna canaliculus), (2) the Pacific Oyster (Magallana gigas, previously Crassostrea gigas) and the Chinook or King Salmon (Oncorhynchus tshawytscha) (Figure 1A), which are exported to 79 countries (AQNZ, 2020a). There are also small aquaculture operations producing Blackfoot Abalone (Haliotis iris) for meat and shell jewellery, seaweed products and freshwater crayfish (Paranephrops sp.). Future species may include a variety of seaweed (currently under investigation), new finfish species like kingfish (Seriola lalandi lalandi) and the Hâpuku (Polyprion oxygeneios).

New Zealand's aquaculture generated 673 million NZ\$ in sales in 2018. The New Zealand Aquaculture sector is eager to grow in response to increasing national and global demand for high quality sustainable aquaculture products (Taylor pers comm); however, many inshore shellfish growing areas have reached their social carrying capacity (Banta and Gibbs, 2009; Peart, 2019; Sinner et al., 2020). Salmon aquaculture is challenged in these same waters by increasing temperatures and low flow sites (Heasman pers comm). Inshore farming space also faces increasing threats from land-based anthropogenic activities that affect the growing environment. Following New Zealand's Aquaculture Strategy (New Zealand Government, 2019) there is a genuine opportunity for the aquaculture industry to reach 3 billion NZ\$ in annual sales and create 6000 + regional jobs by 2035 (Post COVID-19 recession not withstanding). Several strategies are being developed for this rapid development: (1) Maximizing the value of existing farms through innovation: that includes better utilization of the product and its ingredients, increasing efficient and sustainable production of high-value species (e.g., King Salmon), the development of new exposed ocean technology and the cultivation of seaweed; (2) Extending into high value land-based aquaculture. Land-based hatcheries will also need to increase their output. This includes the cultivation of juveniles that better withstand climate change, pests and diseases as well as provide better growth and feed efficiency; (3) Extending aquaculture into the open ocean: expanding operations into more exposed marine sites to facilitate the intended growth of the sector. These developments will be supported by innovative and robust production system design. The perspective offered in this paper will place emphasis on the latter strategy (point 3) with a focus on the Greenshell ${ }^{\mathrm{TM}}$

${ }^{1}$ US $\$ 1=$ NZ\$1.58 at time of writing

${ }^{2} \mathrm{FOB}=$ Free on Board

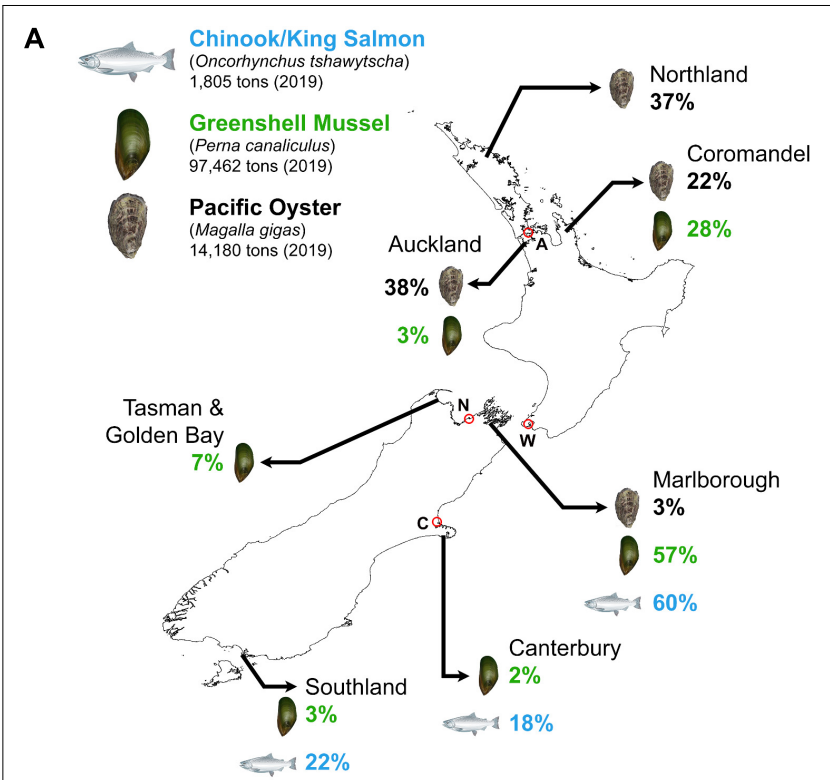

B

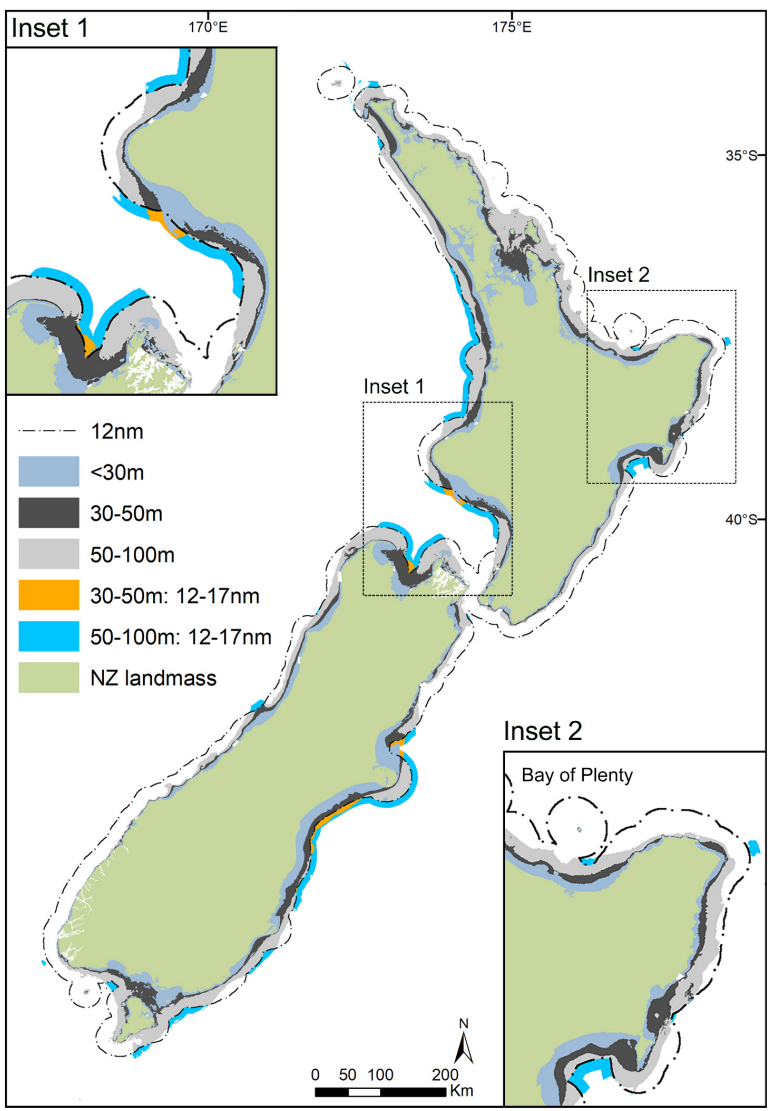

FIGURE 1 | Map of the bathymetry and potential area for aquaculture in New Zealand: (A) shows the culture regions of the three primary marine aquaculture species found in New Zealand displayed either in total production tons.species ${ }^{-1}$ and species in $\% \cdot \operatorname{area}^{-1}$; (B) shows the different available areas for aquaculture divided into isobaths: $30-50 \mathrm{~m}$ and $50-100 \mathrm{~m}$ within the territorial sea as well as 30-50 m and 50-100 m within the 12 to 17 nautical mile zone beyond the territorial sea. (Salmon and mussel images from Illustration(C2020, Eden Cartwright, Bird Circus). 
mussel as this is the most dominant species in the open ocean development so far (Chinook Salmon is expected to be the most valuable aquaculture species in New Zealand in the future). Single seed, hatchery produced shellfish such as oysters and scallops are also considered as they lend themselves well to current aspirations.

\section{THE NEW ZEALAND SITUATION}

\section{Extending Aquaculture Production Into More Exposed Sites}

To fulfill the criterion and potential mentioned above and expand the aquaculture frontier New Zealand is extending operations into the open ocean, (alternatively commonly called Open Ocean Aquaculture (OOA), Offshore Aquaculture or Exposed Aquaculture). Lead by research, marine farmers, businesses, regulators and communities the expansion is gaining momentum (Bay of Connections Aquaculture Strategy, 2018). The New Zealand Ministry for Business, Innovation and Employment (MBIE) has assisted this development by funding a 5 year program entitled "enabling open ocean aquaculture" which started in 2016. The idea of extending aquaculture into more exposed energy rich waters started in various parts of world in the 1980's and since then a variety of technical structures have been considered and developed (see: Polk, 1996; Hesley, 1997; Stickney, 1998; Bridger and Costa-Pierce, 2003; Ryan, 2004; Buck and Langan, 2017).

New Zealand's coastal waters are extensive (Figure 1B.). To demarcate potential areas for open ocean shellfish aquaculture, we selected a minimum depth of $30 \mathrm{~m}$ for shellfish aquaculture in exposed sites, because of the high lateral energy generated by large waves in shallow water. With current technology, it is believed that $50 \mathrm{~m}$ depth would be the deepest depth of the safe structural deployment zone, with the $100 \mathrm{~m}$ depth being the medium-term depth maxima. A zone extending to the $17 \mathrm{NM}$ line was also examined, representing the short to medium term efficient vessel access maxima. The two insets shown in Figure 1B are random coastal zones showing the variation in depth and distances found on the New Zealand coast, with two zones in the territorial sea at depths of 30-50 m (dark gray, total area $=33,803 \mathrm{~km}^{2}$ ) and $50-100 \mathrm{~m}$ (light gray, total area $=39,535 \mathrm{~km}^{2}$ ). There are two regions of up to $5 \mathrm{NM}$ beyond the territorial sea in the EEZ [30-50 m = blue, (total area $1,587 \mathrm{~km}^{2}$ ) and 50-100 $\mathrm{m}=$ orange, (total area $10,274 \mathrm{~km}^{2}$ )]. Figure 1B (highlighted in insert 1 and 2). Assuming a production rate for exposed ocean farming of about $700 \mathrm{t} / \mathrm{km}^{2}$ (MFA, 2012) and a desire for a significant increase in the production of mussels according to New Zealand Government (2019), an area of approximately $200 \mathrm{~km}^{2}$ is required to fulfill the strategy. The $200 \mathrm{~km}^{2}$ area required for this production represents just $0.3 \%$ of the total area from the $30 \mathrm{~m}$ bathometric line to the $17 \mathrm{NM}$ line.

Offshore shellfish farming at these exposed sites will be challenging with current technology used in the inshore farms, although advancements are being made. At high energy open ocean sites, there is a greater failure rate, more maintenance required, and such operations are more expensive.
Due to the high value of salmon and finfish, innovative open ocean finfish farming systems are rapidly evolving in the northern hemisphere. For example, the Norwegian Ministry of Fisheries and Coastal Affairs announced free development concession grants for up to 15 years for the development of technologies that can solve the environmental problems as well as the scarcity of suitable areas of the aquaculture sector. The Norwegian Government is an early adopter of this sector's development and as a consequence, there has been enormous investment in the development of fish pen types and sizes by industry, such as the "Marine Donut" and the "Egg" (both Marine Harvest), large vessel structures (NSK Ship Design) and the Ocean Farm 1 (Salmar) (Buck et al., 2018). In contrast, systems for shellfish farming in exposed environments are progressing with new engineering concepts and new farming approaches. These systems will need to maximize the sustainable production potential of shellfish in the challenging $\mathrm{OOA}$ environment to give the aquaculture industry confidence to invest.

\section{Structural Considerations for Shellfish Structures in Exposed Ocean Conditions}

For shellfish farming to expand into exposed ocean areas, it is not feasible to simply copy the inshore system design, increase the rope thickness, and make anchor systems heavier, or shackles larger. New developments will require a technological revolution, i.e., new structures that are stable and robust in high-energy situations. Systems will need to biologically support cultured species, while being sustainable and economically viable in the long term. For certain situations when culturing mussels, oysters and scallops, it will be necessary to submerge the structures (temporarily or permanently) depending on weather and oceanographic conditions. By submerging the structures, wave energy can be reduced proportionately with depth, but this may be costly as submerged structures can be expensive, complex to deploy, time consuming to operate and difficult to service, potentially reducing their benefit and uptake.

Such challenges are being addressed in New Zealand with innovative designs and technology (e.g., Figure 2). These challenges are a focus of New Zealand researchers, industry partners, and overseas collaborators.

Newly developed submerged structures that can tolerate higher wave and water current velocities, are part of new technologies being investigated. These encompass eight design goals: (1) are large enough to show sufficient economic potential at the required investment cost, (2) are robust enough to survive a $6 \mathrm{~m}$ wave and $0.8 \mathrm{~m} \mathrm{~s}^{-1}$ current velocity (3) can be used to grow more than one aquaculture species, (4) can be used in worst-case scenarios (e.g., storms) by automatically lowering themselves below the sea surface, (5) can be equipped with easy to use buoyancy concepts that can be changed over time via a smart device, (6) are designed with moorings concept allowing easy handling, (7) suitable operations and maintenance and harvesting concepts, and (8) innovative materials that are robust 


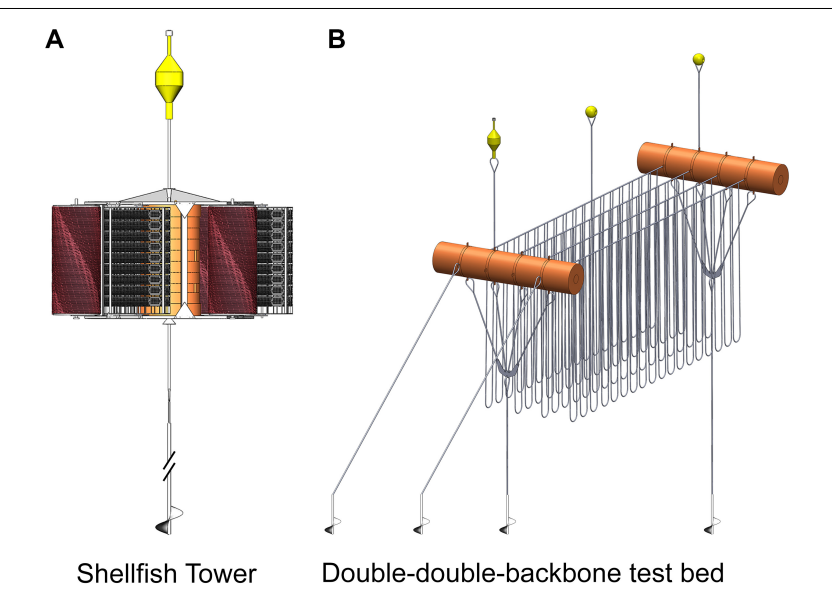

FIGURE 2 | (A) The shellfish tower device on the left and (B) the double-double-backbone test bed on the right.

but not excessively heavy, and not exclusively based on plastic materials.

The enabling OOA Program, funded by the New Zealand Ministry of Business, Innovation and Employment (MBIE) is primarily focused on shellfish (mussels, oysters). However, by facilitating the farming of these two species in OOA, other species may be accommodated, e.g., scallops and seaweeds. The planned structures include continuous culture devices as well as trays or bags for single seed bivalves (species that are not attached to any medium e.g., scallops, oysters). Finding the balance between making the structure large enough to produce commercially viable volumes of product, controlling the movement and behavior of the structures in high-energy situations, and making them strong enough to tolerate the environmental demands, is challenging.

The continuous mussel line system that is currently used for inshore mussel culture in New Zealand is an efficient system for producing and handling mussels in calm waters. However, the system behaves differently in more challenging conditions where surface flotation transfers energy to the structure and, depending on its orientation to waves and water currents, increases wear and product loss. Circular systems with a continuous line are robust but costly, difficult to handle, and inefficient per unit area production. This makes it difficult to build into "revolutionary" systems without a continuous linear mussel line. However, with a clear objective of innovation, two general approaches with the greatest potential were developed and subsequent structural designs were advanced in New Zealand waters.

Two themes were developed further using adapted ORCA Flex software, which models system performance in various virtual weather conditions. The best designs were modeled and scaled for testing in a wave basin. Designs included research on the drag coefficients of mussels (Landmann et al., 2019) and were scaled for realistic data gathering in the wave basin.

Two structures are currently in their prototype field-testing phase. The first structure is a single-point-mooring device for oyster culture and Greenshell ${ }^{\mathrm{TM}}$ Mussel spat catching. The, second structure is a double-double-backbone-based suspended and submergible grow-out design (Figure 2). The spat catching structure, referred to as the "shellfish tower" and the double-double-backbone test bed (Gieschen et al., submitted; Heasman et al., submitted) are both deployed at the same exposed location $6 \mathrm{NM}$ off the coast of Opotiki (Bay of Plenty, North Island).

Site-specific data such as wave orientation and water current direction are enabling testing to include: how often the new structures will need maintenance visits; how durable the material will be and how culture species survive and grow. In the future these structures will likely include remotely controlled systems, which allow the structure's depth to be adjusted to avoid excessive energy and/or to seek better environmental conditions (e.g., cooler water at depth). Optimally these processes would be automated, reducing crew safety issues, providing information of system status and reducing unnecessary boat trips to farms while reducing the carbon footprint. Mooring systems may be single or complex matrix systems depending on the structure.

\section{Aquaculture and Climate Change in the Exposed Ocean}

Climate change in New Zealand waters is of increasing importance when assessing and predicting the sustainability of aquaculture and marine systems. Coastal acidification has already had significant impacts on coastal aquaculture operations around the world (Ekstrom et al., 2015). Marine heatwaves (defined as warm water anomalies occurring for up to months in duration, and thousands of kilometers in size; Hobday et al., 2018) are increasingly common, causing summer mortalities and increased disease in aquaculture species (Oliver et al., 2017). In coastal areas, acidification and warming also act synergistically with anthropogenic inputs such as eutrophication and sedimentation from increasing land use (Law et al., 2018a). The exacerbation of these environmental changes in coastal areas presents a compelling case for the expansion of coastal aquaculture into the open ocean, and diversification into farming other species.

In terms of non-human fed aquaculture species, such as shellfish, influences of climate change could include (1) negative effects of acidification on calcifying life stages (Salisbury et al., 2008; Ericson, 2010; Barros et al., 2013; Law et al., 2018a; Ragg et al., 2019), (2) changes in the abundance of food sources (e.g., phytoplankton) (Law et al., 2018a,b), (3) greater fluctuations in temperature and salinity (Dunphy et al., 2013, 2015; Newton and Webb, 2019), (4) novel disease threats (Keeling et al., 2014), (5) increases in biosecurity incursions and/or biofouling species and (6) increases in the frequency of storm events.

The open ocean environment may offer some inertia to the rate of change in thermal and $\mathrm{pH}$ parameters and may alleviate the negative impacts on shellfish aquaculture. It does not, however, solve all issues related to climate change. The prospect of farming in the open ocean under 
varying conditions does allow the industry the opportunity to select or move farms into areas best suited for sustainable production. The possibility of using seaweed as a carbon dioxide sink will rely on the increased value of carbon credits and a degree of philanthropy, at least in the shortterm, to cover capital and production costs. Fast-growing algae such as Undaria sp. and Macrocystis sp. have significant potential to capture carbon (Duarte et al., 2017). Farming them economically, however, will require extremely large areas (i.e., thousands of hectares) as they can only be cultured in the upper $10 \mathrm{~m}$ of the water column. These species have been included in the OOA Program to better understand their potential to support production and sequester atmospheric carbon.

\section{Socio-Economics}

Economic influences are difficult to quantify as they are site and species specific. In general, more robust equipment, challenging access windows for operations and maintenance, distance to service ports and required structure or system modification all add a level of uncertainty, risk, and cost to open ocean aquaculture (Hoagland et al., 2003; Kite-Powell et al., 2003; Jin et al., 2005; Jin, 2008; Thomas et al., 2019). Despite these demands, open ocean aquaculture can be profitable (Hoagland et al., 2003; Thomas et al., 2019; Envirostrat Ltd, 2020), and it is already underway in places like the Bay of Plenty, New Zealand, where it will have considerable socioeconomic benefits (AQNZ, 2020b). As mentioned in section "Extending Aquaculture Production Into More Exposed Sites," only a very small area $(0.3 \%$, Figure $1 B)$ of the available open ocean is required for the national mussel production to more than double. Thus, the prospects for this sustainable industry are significant.

The integrated social, regulatory, and customary drivers around aquaculture in New Zealand are complex and outside the scope of this document. Perspectives on these complexities were previously discussed in Banta and Gibbs (2009), who show that social factors such as landscape and amenity values, recreational and navigational use, and alienation of public space are the most frequently cited reasons of community disenchantment with aquaculture development. More recently, Peart (2019) considered the requirement for legislative reform that specifically provides for the aquaculture industry and protects and facilitates environmental restoration. Sinner et al. (2020) measured social license in relation to aquaculture and indicated that of the factors related to aquaculture operations and industry performance, the quality of a person's contacts with the industry (i.e., whether interactions were informative, respectful, pleasant and positive) was the strongest and most consistent predictor of that person's social license rating for the company or industry. Their findings were also consistent with work by the New Zealand aquaculture industry, which concluded that social license requires longer-term "relational" interactions (based on aligned values and socio-emotional factors), rather than transactional relationships (based on exchange or compensation), with communities and stakeholders (Baines and Edwards, 2018).

\section{DISCUSSION AND OUTLOOK}

"New Zealand's vision is to be globally recognized as a worldleader in sustainable and innovative aquaculture management across the value chain" (New Zealand Government, 2019). Favorable features of the open ocean marine environment include significant space for the expansion of the aquaculture industry; impressive carrying and assimilative capacity; fewer stakeholder interactions, limited or no exposure to human sources of pollution; and optimal environmental conditions for a wide variety of marine species to easily reach New Zealand's sector targets (Holm et al., 2017). New Zealand has sufficient water area to realize these opportunities. Even with access constraints, marine parks, other user pressure, depth and weather, to increase New Zealand's shellfish production by $150,000 \mathrm{t}$ will require less than $0.3 \%$ of the available suitable space as we have defined it. Increasing technological efficiency through structural design, automation, and remote sensors (such as those described in this paper) will improve the economic viability, sustainability, and resilience of OOA.

The OOA space availability and the novel farming equipment that is in development present unrivaled opportunity to overcome inshore challenges associated with shared use and coastal climate change (O'Shea et al., 2019), and the Government agreement to extend aquaculture into the open ocean to realize New Zealand's goals in this sector. It will become more efficient with time and if planned carefully will be an increasingly sustainable operation.

\section{DATA AVAILABILITY STATEMENT}

All datasets generated for this study are included in the article, further inquiries can be directed to the corresponding author/s.

\section{AUTHOR CONTRIBUTIONS}

$\mathrm{KH}$ : marine scientist and open ocean aquaculture project leader at the Cawthron Institute and lead author of the article. NS: open ocean aquaculture project field manager and contributor to the article. JE: marine scientist focused on climate change influences and contributor to the article, with specific reference to climate change. DT: marine scientist and technical director to Aquaculture New Zealand, an aquaculture industry support organization and contributor to the article including editing. BB: professor and advisor to the open ocean aquaculture project and contributing author to the article, including editing. All authors contributed to the article and approved the submitted version. 


\section{FUNDING}

This document was funded by the New Zealand Ministry of Business, Innovation and Employment program number CAWX16408 and the Cawthron Institute, New Zealand.

\section{REFERENCES}

AQNZ (2020a). Aquaculture New Zealand Organisation, Nelson, New Zealand Available online at: https://www.aquaculture.org.nz (accessed February 18 2020).

AQNZ (2020b). Mussels Revitalizing Opotiki. Available online at: https: //www.aquaculture.org.nz/2020/06/10/mussel-power-revitalising-opotiki/ (accessed February 8, 2020).

Baines, J., and Edwards, P. (2018). The role of relationships in achieving and maintaining a social licence in the New Zealand aquaculture sector. Aquaculture 485, 140-146. doi: 10.1016/j.aquaculture.2017.11.047

Banta, W., and Gibbs, M. (2009). Factors controlling the development of the aquaculture industry in New Zealand: legislative reform and social carrying capacity. Coast. Manag. 37, 170-196. doi: 10.1080/08920750902758473

Barros, P., Sobral, P., Range, P., Chícharo, L., and Matias, D. (2013). Effects of seawater acidification on fertilization and larval development of the oyster Crassostrea gigas. J. Exper. Mar. Biol. Ecol. 440, 200-206. doi: 10.1016/j.jembe. 2012.12.014

Bay of Connections Aquaculture Strategy (2018). Available online at: https://www.bayofconnections.com/downloads/070819_FINAL-DOC SPR18016-Aquaculture-PAGES.pdf (accessed June 2020).

Bridger, C. J., and Costa-Pierce, B. A. (2003). Open Ocean Aquaculture: from Research to Commercial Reality. Baton Rouge, LA: The World Aquaculture Society.

Buck, B. H., and Langan, R. (2017). "Aquaculture perspective of multi-use sites in the open ocean," in The Untapped Potential for Marine Resources in the Anthropocene, eds B. H. Bela and L. Richard (Cham: Springer), 404

Buck, B. H., Troell, M., Krause, G., Angel, D., Grote, B., and Chopin, T. (2018) State of the art and challenges for multi-trophic offshore aquaculture. Front Mar. Sci. 5:165. doi: 10.3389/fmars.2018.00165

Dawbar, C. (2004). Lines in the Water. Picton: River Press.

Duarte, C. M., Wu, J., Xiao, X., Bruhn, A., and Krause-Jensen, D. (2017). Can seaweed farming play a role in climate change mitigation and adaptation? Front Mar. Sci. 4:100. doi: 10.3389/fmars.2017.00100

Dunphy, B. J., Ragg, N. L. C., and Collings, M. G. (2013). Latitudinal comparison of thermotolerance and HSP70 production in F2 larvae of the greenshell mussel (Perna canaliculus). J. Exp. Biol. 216, 1202-1209. doi: 10.1242/jeb.076729

Dunphy, B. J., Watts, E., and Ragg, N. L. C. (2015). Identifying thermally-stressed adult green-lipped mussels (Perna canaliculus Gmelin, 1791) via metabolomic profiling. Am. Malacol. Bull. 33, 1-9.

Ekstrom, J. A., Suatoni, L., Cooley, S. R., Pendleton, L. H., Waldbusser, G. G., and Cinner, J. E. (2015). Vulnerability and adaptation of US shellfisheries to ocean acidification. Nat. Clim. Chang. 5, 207-214. doi: 10.1038/ nclimate 2508

Envirostrat Ltd (2020). Open Ocean Finfish Aquaculture: Business Case. Report Prepared for New Zealand Trade and Enterprise. Auckland: Envirostrat Ltd.

Ericson, J. A. (2010). Effects of Ocean Acidification on Fertilisation and Early Development in Polar and Temperate Marine Invertebrates. MSc thesis, University of Otago, Dunedin.

Hesley, C. (1997). "Open ocean aquaculture: chartering the future of ocean farming," in Proceedings of an International Conference, Maui.

Hoagland, P., Kite-Powell, H. L., and Jin, D. (2003). Business Planning Handbook for the Ocean Aquaculture of Blue Mussels. Woods Hole, MA: Woods Hole Oceanographic Institute.

Hobday, A. J., Oliver, E. C. J., Sen Gupta, A., Benthuysen, J. A., Burrows, M. T., Donat, M. G., et al. (2018). Categorizing and naming marine heatwaves. Oceanography 31, 162-173.

Holm, P., Buck, B. H., and Langan, R. (2017). "Introduction: new approaches to sustainable offshore food production and the development of offshore platforms," in Aquaculture Perspective of Multi-Use Sites in the Open Ocean: The

\section{ACKNOWLEDGMENTS}

We acknowledge colleagues at the Cawthron Institute and within the New Zealand aquaculture industry for their support.

Untapped Potential for Marine Resources in the Anthropocene, eds B. H. Buck and R. Langan (Berlin: Springer), 1-20. doi: 10.1007/978-3-319-51159-7_1

Jin, D. (2008). "Chapter 6: economic models of potential U.S. offshore aquaculture operations," in Offshore Aquaculture in the United States: Economic Considerations, Implications and Opportunities, ed. R. Michael (Silver Spring, MD: NOAA Aquaculture Program), 263. doi: 10.1016/j.aquaculture.2008.03.043

Jin, D., Kite-Powell, H., and Hoagland, P. (2005). Risk assessment in open-ocean aquaculture: a firm-level investment-production model. Aquac. Econ. Manag. 9, 369-387. doi: 10.1080/13657300500 242261

Keeling, S. E., Brosnahan, C. L., Williams, R., Gias, E., Hannah, M., Bueno, R. et al. (2014). New Zealand juvenile oyster mortality associated with ostreid herpesvirus 1-an opportunistic longitudinal study. Dis. Aquat. Organ. 109, 231-239. doi: 10.3354/dao02735

Kite-Powell, H. L., Hoagland, P., and Jin, D. (2003). "Economics of open ocean grow-out of shellfish in New England: sea scallops and blue mussels," in Open Ocean Aquaculture: from Research to Commercial Reality, eds C. J. Bridger and B. A. Costa-Pierce (Baton Rouge, LA: The World Aquaculture Society), 293-306.

Landmann, J., Ongsiek, T., Goseberg, N., Heasman, K., Buck, B., Paffenholz, J., et al (2019). Physical modelling of blue mussel dropper lines for the development of surrogates and hydrodynamic coefficients. J. Mar. Sci. Eng. 7:65. doi: 10.3390/ jmse7030065

Law, C. S., Bell, J. J., Bostock, H. C., Cornwall, C. E., Cummings, V. J., and Currie, K. (2018a). Ocean acidification in New Zealand waters: trends and impacts. N. Z. J. Mar. Freshw. Res. 52, 155-195. doi: 10.1080/00288330.2017.137 4983

Law, C. S., Rickard, G. J., Mikaloff-Fletcher, S. E., Pinkerton, M. H., Behrens, E., Chiswell, S. M., et al. (2018b). Climate change projections for the surface ocean around New Zealand. N. Z. J. Mar. Freshw. Res. 52, 309-335. doi: 10.1080/ 00288330.2017 .1390772

MFA (2012). Aquaculture in Golden Bay and Tasman Bay Fact Sheet 2012 Blenheim: Marine Farming Association.

Migiro, G. (2018). Countries with the Largest Exclusive Economic Zones. Available online at: https://www.worldatlas.com/articles/countries-with-thelargest-exclusive-economic-zones.html (accessed March 3, 2020).

New Zealand Government (2019). The New Zealand Government Aquaculture Strategy. Wellington: New Zealand Government.

Newton, M., and Webb, S. C. (2019). Summer Mortality of Green-Lipped Mussels 2017-18: A Survey of New Zealand Mussel Farmers. Cawthron Report No. 3258. Available online at: www.cawthron.org.nz

Oliver, E. C. J., Benthuysen, J. A., Bindoff, N. L., Hobday, A. J., Holbrook, N. J. Mundy, C. N., et al. (2017). The unprecedented 2015/16 Tasman Sea marine heatwave. Nat. Commun. 8:16101.

O’Shea, T., Jones, R. M., Norell, A., Scott, E., Theuerkauf, J., and Waters, T. (2019). Towards a Blue Revolution: Catalyzing Private Investment in Sustainable Aquaculture Production Systems. Arlington, VA: The Nature Conservancy and Encourage Capital.

Peart, R. (2019). Farming the Sea: Marine Aquaculture Within Resource Management System Reform. Auckland: Environmental Defence Society.

Polk, M. (1996). "Open ocean aquaculture," in Proceedings of an International Conference, Portland.

Ragg, N., Gale, S., Le, D., Hawes, N., Burritt, D., Young, T., et al. (2019). The effects of aragonite saturation state upon hatchery-reared Greenshell mussel larvae (Perna canaliculus). J. Shellf. Res. 38, 779-793. doi: 10.2983/035.038. 0328

Ryan, J. (2004). Farming the Deep Blue. Washington, DC: ACS. 
Salisbury, J., Green, M., Hunt, C., and Campbell, J. (2008). Coastal acidification by rivers: a threat to shellfish? EOS Trans. Am. Geophys. Union 89, 513-528. doi: $10.1029 / 2008$ eo500001

Seafood New Zealand (2019). Seafood New Zealand Report 7. Available online at: https://www.seafoodnewzealand.org.nz/fileadmin/documents/Export_data/ 19.12.7.pdf (accessed March 3, 2020).

Sinner, J., Newton, M., Barclay, J., Baines, J., Farrelly, T., Edwards, P., et al. (2020). Measuring social licence: what and who determines public acceptability of aquaculture in New Zealand? Aquaculture 521:734973. doi: 10.1016/j. aquaculture.2020.734973

Stickney, R. R. (1998). “Joining forces with industry - open ocean aquaculture," in Proceedings of the Third Annual International Conference, Corpus Christi, TX.

Te Ahukaramû Charles Royal (2020). Tangaroa-the Sea - The Importance of the Sea', Te Ara - the Encyclopaedia of New Zealand. Available online at: http://www.TeAra.govt.nz/en/tangaroa-the-sea/page-1 (accessed July 23, 2020).
Thomas, L. R., Clavelle, T., Klinger, D. H., and Lester, S. E. (2019). The ecological and economic potential for offshore mariculture in the Caribbean. Nat. Sustain. 2, 62-70. doi: 10.1038/s41893-018-0205

Conflict of Interest: KH, NS, and JE were employed by the company Cawthron. $\mathrm{BB}$ has been an advisor to a project managed by the company Cawthron. DT is employed by Aquaculture New Zealand, an industry body representing the New Zealand Aquaculture Industry.

Copyright (c) 2020 Heasman, Scott, Ericson, Taylor and Buck. This is an openaccess article distributed under the terms of the Creative Commons Attribution License (CC BY). The use, distribution or reproduction in other forums is permitted, provided the original author(s) and the copyright owner(s) are credited and that the original publication in this journal is cited, in accordance with accepted academic practice. No use, distribution or reproduction is permitted which does not comply with these terms. 